\title{
Adalék a pécsi székesegyház 12. századi építkezéséhez és a Sámson ciklus értelmezéséhez
}

\author{
M. ARADI CSILLA \\ SMKH - KJH - Építésügyi és Örökségvédelmi Osztály, 7400 Kaposvár Nagy Imre tér 1., \\ e-mail: csiaradi@freemail.hu
}

\begin{abstract}
M. ARADI, Cs: Additional information to the 12. C. construction of the cathedral of Pécs and to the interpretation of the Samson cycle.

Abstract: The paper deals with the 12. C. reconstruction of the Cathedral of Pécs. The romanesque reliefs now decorating the entrance zone of the crypt are in their secondary position. Through thorough examination the possibility of a great western front arises. Within the reliefs of the Samson cycle the so-called tree-pulling Samson depicts a unique representation. Various impects yielded in the formation of the medieval conception of the Samson figure.
\end{abstract}

Keywords: west front, Samson, romanesque, Ripoll, Porta Speciosa

\section{A pécsi székesegyház románkori kialakítása}

A pécsi székesegyház építéstörténetének számos problematikája közül jelen dolgozat célja a 12 . századi építkezések során tapasztalt megfigyelések összeszedése és esetleges értelmezése, valamint a Sámson ciklus gyökereinek és párhuzamainak feltérképezése volt.

A művészettörténeti kutatások, régészeti feltárások eredményei, a mai álló épület és a 18-19. századi felmérések, ábrázolások tanulmányozása, valamint az írott források ismerete révén már eddig is sok kísérlet történt a székesegyház románkori periódusainak elkülönítésére, kölcsönhatásainak, összefüggéseinek megismerésére. ${ }^{1}$

A 12. századi építkezéseket gyakran a kutatók egy egészként értelmezik, azonban a nagy időintervallum miatt is feltehetöen több, külön építési periódust foglal magába. A háromhajós, keresztház nélküli bazilika négy sarkán kívülröl csatlakozó tornyokkal és a keleti fele alatt elhelyezkedő öthajós, keresztboltozatos csarnokkriptával egyedi elrendezést mutat, több irányból érkező impulzusokat egyesít. ${ }^{2}$ A mellékhajók kiképzése belül egyenes, kívül félköríves. A kereszthajó nélküli elrendezés tekintetében tagadhatatlan a lombard építészet hatása, azonban a saroktornyok megléte német irányból érkező befolyásról tanúskodik, ahogy a kripta középső szakaszának korábban nyitott volta - kvázi kétszintes kápolna funkciója is.

Salamon újrakoronázását követő tüzvész 1064-es pusztításának erejét csak gyaníthatjuk, azt azonban jogosan feltételezhetjük, hogy a király, koronázásának helyszínét nem hagyta romba dőlni, így a felújítás

1 A pécsi székesegyház kutatástörténeti összefoglalóját Id. Buzás 2013

2 A lombard párhuzamokra ld. Buzás 2013. 17. rögtön megkezdődhetett. ${ }^{3}$ A székesegyház középkori formáját - legalább is részben - ezzel az építkezéssel alakították ki. Abban egyetért a kutatás, hogy a kripta és szentélyrész a két toronnyal egy időben készült el, bár az ÉK-i torony másodlagosan felhasznált, faragott kövekböl készült alapfala az altemplom öntött szerkezetủ alapfalaitól jelentősen eltér. ${ }^{4} \mathrm{Ha}$ tekintetbe vesszük a kialakult alaprajzot, úgy tünik, hogy az építkezések menetében az uralkodó tevékeny részt vállalhatott. Salamon házassága révén kötődött a Száli dinasztiához tartozó IV. Henrik német-római császárhoz, akinek húgát, Juditot vette el. A német-római császári kapcsolatokból merített a Pécsi székesegyház kialakítása során, amelyhez a nagyméretű kripta tartozott.

A Száli dinasztia temetkezési helyét, a Speyeri dómot több mint 30 év építkezés után 1061-ben szentelték fel, ekkor már a Westwerk, a háromhajós, kereszthajós szerkezet és a szentély melletti két torony is megépült. A monumentális, $850 \mathrm{~m}^{2}$ területü kripta még 1041-ben elkészült. IV. Henrik 1090-1106 között pedig a katedrálist megnagyobbította és újjáépítette, az első periódusból csak a kripta maradt érintetlen. A templomhajót ekkor megemelték és keresztboltozattal látták el.

A másik kiemelkedően nagy kriptával bíró templom az antik gyökerekkel is rendelkező kölni Szent Gereon templom. 1067/69 körül, II. Anno érseksége alatt történt a kórus és a kripta végleges kialakítása. A később szentté avatott, nagy befolyással bíró érsek 1063-1065 között a kiskorú IV. Henrik mellett a régensi tisztséget töltötte be. A 12. század közepi és a 13. század eleji átépítések már nem befolyásolták a kripta formáját, mely a Dekagon előtti templom teljes területe alá benyúlt. Hasonlóan a pécsi székesegyházhoz, DNy felé egy antik kápolna is csatlakozott a templomhoz.

Úgy tünik, hogy a pécsi székesegyház kriptájának különleges mérete nemcsak a Dijoni Szent Benignusz bencés monostor (és a későbbi Gurki dóm) kriptájával állítható párhuzamba, hanem a németországi Száli és Hohenstauf dinasztia építkezéseivel, valamint északolasz hatásokkal is - ami korban és kapcsolatokban jobban magyarázható.

3 Thuróczy Krónika, Szőnyi 1906. 17. Hasonlóképpen tűzvész miatt folyt az átépítés Esztergomban Jób érsek alatt (1188-1198). A székesfehérvári bazilika III. Béla-kori átépítéséröl is tudunk. Úgy tünik, hogy a 12. század végén az uralkodói támogatás nyomán zajló építkezések köréhez Pécs is csatlakoztatható.

4 Buzás 2013.13. 


\section{A 12. századi építkezések elkülönítése}

A pécsi székesegyház 12. századi építési periódusainak elkülönítését a Schmidt-féle átalakítás előtt keletkezett Koller-féle felmérés nagyban elősegíti. (1. ábra) Ezen a felmérésen a föapszis É-i oldalán kivehető egy kisebb románkori ablak, melyet egy nagyobb - később befalazott ablakkal vágtak át. Úgy tűnik, hogy az apszis átépítése tehát még a románkorban bekövetkezett. ${ }^{5}$ $\mathrm{Az}$ ablak felett egy vakárkádos, farkasfogas párkány maradványait lehet megfigyelni. Az ilyen párkányok az apszisoknál általában a koronapárkány szerepét töltik be, tehát a tető közvetlen közelében találhatók, és csak a tornyoknál jeleznek szinteket. Az eredeti főapszis magasság tehát alacsonyabb lehetett és feltehetően a gótikus átépítés során emelték meg. ${ }^{6}$

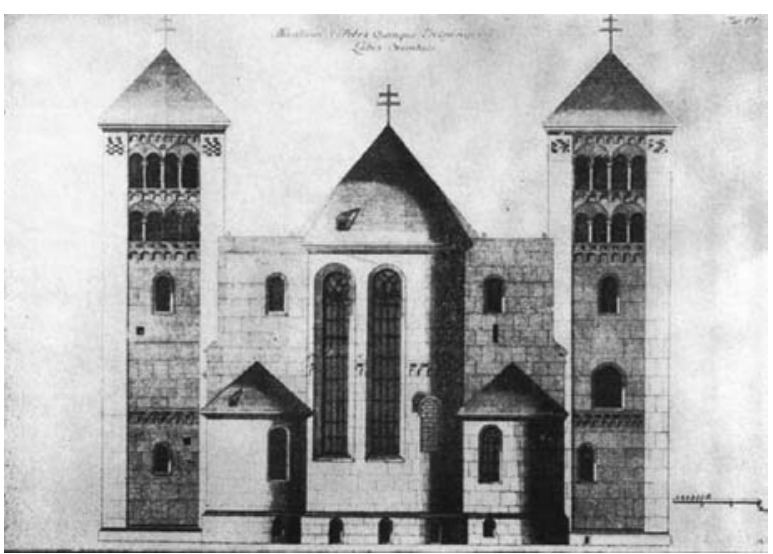

csatorna fala, beszűkülése, ÉNy-i fal eltérő alapozása ezt támasztanák alá). ${ }^{9}$ A nyugati homlokzat fökapu feletti ablakainak hármas tagolása melletti két szélső ablak aszimmetrikus elhelyezése szintén problematikus. Az északi ablak nagyon az északi fal szélére került, talán ez is az ÉNy-i rész átépítését támasztja alá.

A két toronypár méretbeli anomáliájára már Gosztonyi is felhívta a figyelmet. A keleti toronypár kisebb mérete, eltérő alapozása, lábazata és az altemplom szintjén jelentkező helyiségeivel szemben a nyugati toronypár építése egyidejünek tünik (a Koller felmérésen egy szinttel alacsonyabb DNy-i torony egy 1631-ben becsapott villám pusztításának köszönhető). ${ }^{10}$ Míg a keleti toronypárnál a mellékapszis párkányok magasságában jelenik meg az első osztópárkány, addig a nyugati toronypárnál ez leginkább a főapszishoz igazodik. A fel-

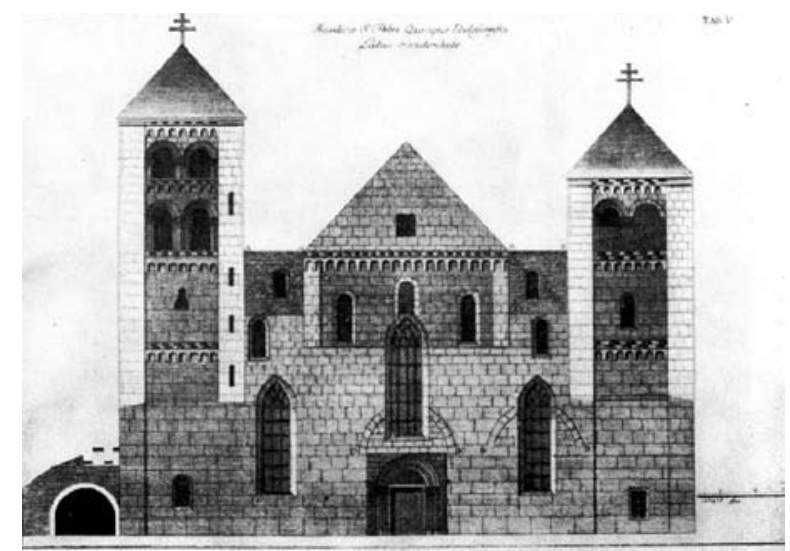

1. ábra. A székesegyház keleti és nyugati homlokzatának 18. századi felmérése (Koller József nyomán)

A nyugati homlokzat korábbi fázisát a középső nyugati kapu és a tőle délre található boltív jelöli, amely a nyugati kapu fölött és mellett egyértelmüen befalazás, és amelyről a felette látható kisebb méretű kövek és a kisméretű kaput körbevevő rizalitszerü téglakeret is tanúskodik. Ezek alapján a kőtárban őrzött nyugati kapu előtt egy másik - talán három kapuval rendelkező homlokzati rendszer maradványait sejthetjük. Ennek a három kapuval rendelkező megoldásnak egyik eklatáns példája a Paviai S. Michele templom Ny-i homlokzata, amelynek kriptahomlokzatának tagolását Buzás is a pécsi székesegyház rekesztőjének előzményként értékeli. ${ }^{7}$ A tervmódosítást támasztja alá a $\mathrm{Ny}$-i pillérpár kialakítása és a déli hosszház nyugati félköríves ablakának keletebbre helyezése is. ${ }^{8} \mathrm{E}$ három kapus megoldástervezet, az északi oldalon egy későbbi átépítés során tünhetett el (az itt észlelhető anomáliák - Id. vízelvezető

5 Szőnyi 1906. 23. Erröl már Czobor Béla is megemlékezett 1882ben. A székesegyházhoz csatlakozó Cella Trichora két középkori kifestési rétege is alátámasztja, hogy a 12. században két ízben is folyt munka a kápolnában. A második kifestés a kufi írásmotívumok alapján a 12. sz. végére tehető. Buzás 2013. 2.

6 Henszlmann Imre a székesegyház föhajójának déli gádorfalánál is hasonló párkányt mért fel. Buzás 2013. 20. A párkány Koller felmérésén a nyugati homlokzaton is megjelenik.

7 Buzás 2013. 38

8 Buzás 2013. 22, 24. A görögkereszt alaprajzú pillérek és a beugró falsíkok egy háromszakaszos karzat tervezésére utalnak. ső ikerablakok, a farkasfogas osztópárkányok, és a koronapárkány folytatásában jelentkező díszítés kialakítása eltérő. Schmidt felvételi rajzán a DK-i torony helyén jelez félköríves ablakot, ami bizonyítja, hogy a torony az altemplom építését követő időszakra tehető. ${ }^{11} \mathrm{Ez}$ is alátámasztja azt a tényt, hogy a székesegyház kiépítése nem egyszerre ment végbe, és bár a Ny-i toronypárnál törekedtek a már meglévő K-i tornyok másolására, ez nem teljesen sikerült, ${ }^{12}$ a Ny-i toronypár felső részét pedig már késő román stílusban alakították ki. A székesegyház nyugati szakaszának későbbi kiépítése mellett szól az is, hogy míg a hosszház alapfalai kváder borításúak, a nyugati szakaszé törtkő. ${ }^{13}$

\section{A nyugati homlokzat lehetséges kialakítása}

A karzattal, hármas kapuval rendelkező nyugati struktúra a korabeli párhuzamok alapján egy jóval díszesebb homlokzat kialakítását feltételezte, főleg ha figyelembe vesszük a szentélyrekesztő és oltárbaldachin díszes kivitelezését is.

9 Boros 2002. 17

10 Gosztonyi 1939. 31-34, 197

11 Gosztonyi 1939. 35

12 Gosztonyi 1939. 197. A Ny-i tornyok korinthoszi ablakoszlop fejezetei is eltérnek a K-i toronypár kockafejezeteitől.

13 Boros 2002. 17 


\section{ADALÉK A PÉCSI SZÉKESEGYHÁZ 12. SZÁZADI ÉPÍTKEZÉSÉHEZ ÉS A SÁMSON CIKLUS ÉRTELMEZÉSÉHEZ}

Milyen lehetett az eredeti tervben megálmodott nyugati homlokzat? Az elökerült faragványok alapján a Ripolli Szűz Mária monostortemplom 1140-ben elkészült nyugati homlokzati megoldását feltételezhetünk, ahol a hét sávban folyó narratív elbeszélést párkányokkal szabdalták. ${ }^{14}$ (2. ábra) A hierarchikus elrendezésű kompozíció két felső sávja a trónon ülő Istent ábrázolja az evangélista szimbólumok, angyalok és a 24 vén körében. A középső sávok balra Dávid és Salamon, míg jobbra Mózes történetét beszélik el, míg alul mitológiai állatok sorjáznak, melyet Dániel próféta látomásaihoz kapcsolnak. A kapu két oldalán Szt. Péter és Pál álló alakja található. Körülöttük többek között Szent Péter és Pál, Káin és Ábel, valamint Jónás és Dániel próféta története mellett, zodiákus jelek kíséretében hónapábrázolásokat láthatunk.

\section{Anomáliák a kriptalejáratok körül}

A kriptalejárók általunk ismert elhelyezkedése szintén nem köthető a templomépítés idejéhez. Már Gosztonyi felfigyelt rá, hogy a Koller-féle déli homlokzat ábrázolásán, a kaputól Ny-ra, az altemplomi lejárat helyén ablaknyílás látható, amelyik az altemplomba nyílt, feltehetően az eredeti lejárat itt, a mellékapszis külső szélén helyezkedett el. ${ }^{16}$ A székesegyház szentélyrekesztőjének alaprajzán is láthatók egyenetlenségek. (3. ábra) A két nagyméretü pillér között, az oltárbaldachin két oldalán jelentkező nagyobb hiátus miatt, itt is elképzelhető volt a kórusba történő feljárás. ${ }^{17}$ A pillérek északi és déli oldalán nem egyező a falszélessség, és a felvezető lépcsőknek is különböző a szélessége. Eltérő a két lejárat mérete, kompozíciójának kialakítása, az

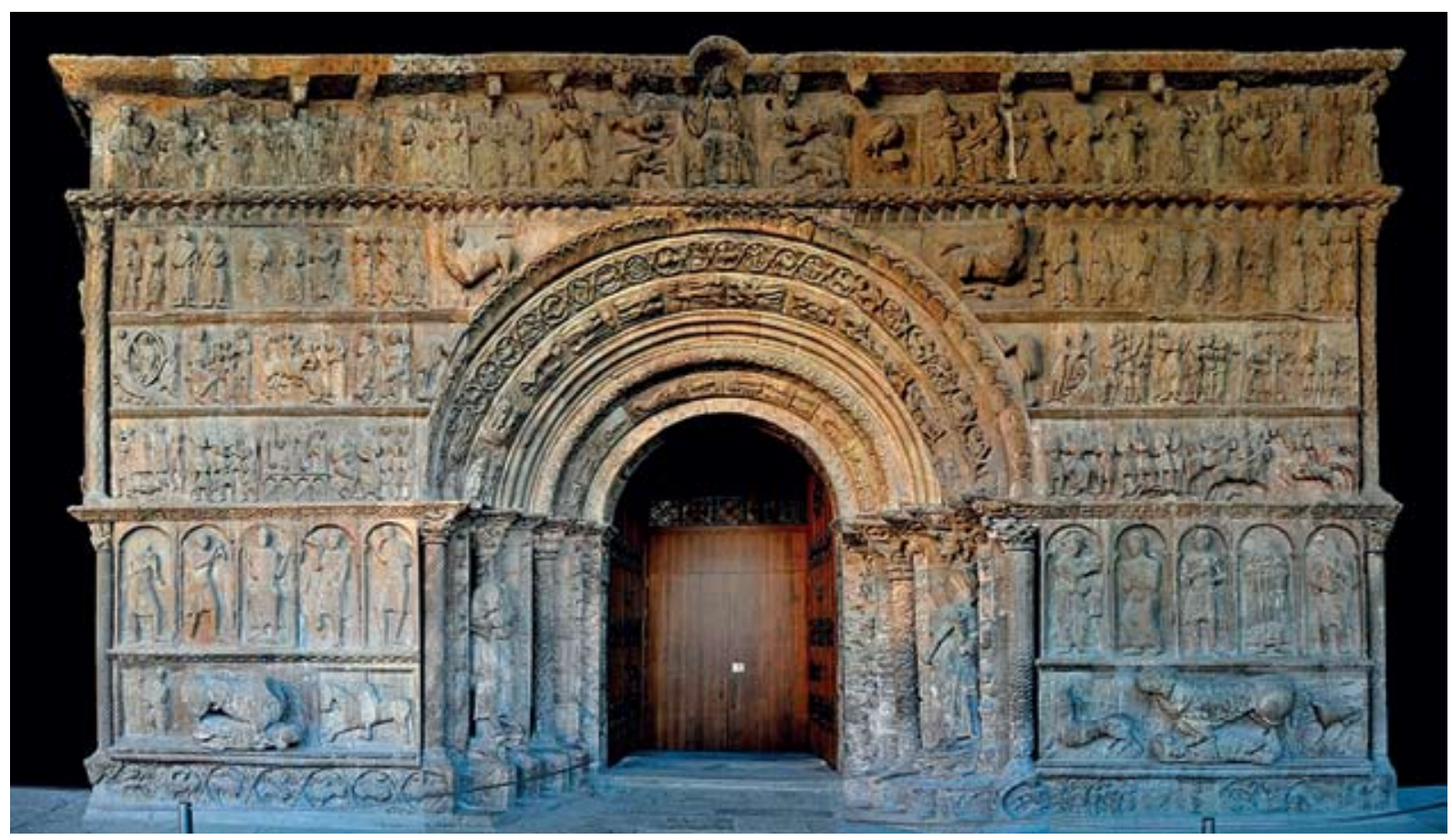

2. ábra. A Ripolli Szüz Mária templom díszített homlokzata

A pécsi székesegyház teljes nyugati homlokzatának díszítettségét a két apostolciklus megléte is alátámasztja, míg a Bertalan apostol nevét feltüntető fülkesoros relief minden bizonnyal ténylegesen a szentélyrekesztő díszítésére szolgált, egy másik, a Máté, Márk, Lukács és Simon nevével fémjelzett apostol sorozat máshol kerülhetett elhelyezésre. ${ }^{15}$

Ennek alapján elképzelhető egy nagy Utolsó Ítélet vagy Mennybemenetel ciklus ábrázolása a nyugati homlokzaton, ahol némiképp hierarchikus rendben állhattak az apostolok, az apokalipszis vénei és az angyalok, míg az alsóbb részen foglalhattak helyet az új- és ótestamentumi jelenetek.

14 A kompozíció szélén és a díszkapunál a pécsihez hasonló, erősen díszített oszlopokat helyeztek el, hasonlóan a regensburgi Szent Jakab templom homlokzatához.

15 Szőnyi 1906. 220-224, 210-211. északi lejáró méretes alsó sora lejjebb kezdődik, mint a délié, és a relief sávok mérete is eltérő. Ugyancsak eltérő a két lejáró kapuzata is, mind méretben, mind kialakításban, ${ }^{18}$ a déli oldali kapu mellett értelmezhetetlen hiátus alakult ki. ${ }^{19} \mathrm{Az}$ északi lejárat nagy Utolsó Ítélet kompozíciója mellett a teremtés és a bűnbeesés található. A keleti oldali kompozíciójának kiegészítése bizonytalan a nagyszámú ide sorolható kőtöredék ismeretében (pl. apokalipszis vénei, feltámadt halottak). Ebben a kompozícióban eredetileg helyet kellett találni az angyalok mellett 24 aggastyánnak is, amelyikből az

16 Gosztonyi 1939. 35., Buzás 2013. 14

17 Már Gosztonyi Gyula is így feltételezte. Buzás 2013. 37.

18 Az É-i félköríves kapu 2,5 m, a D-i egyenesen záródó pedig $2 \mathrm{~m}$ magas.

19 Nagy 1983. 331. Nagy Emese figyelte meg a D-i lejárónál az egyenes ajtó fölé készült párkányok boltozatszerủ megoldását, ami azonban nem bizonyíja azt, hogy az ajtó eredeti helyén van. 


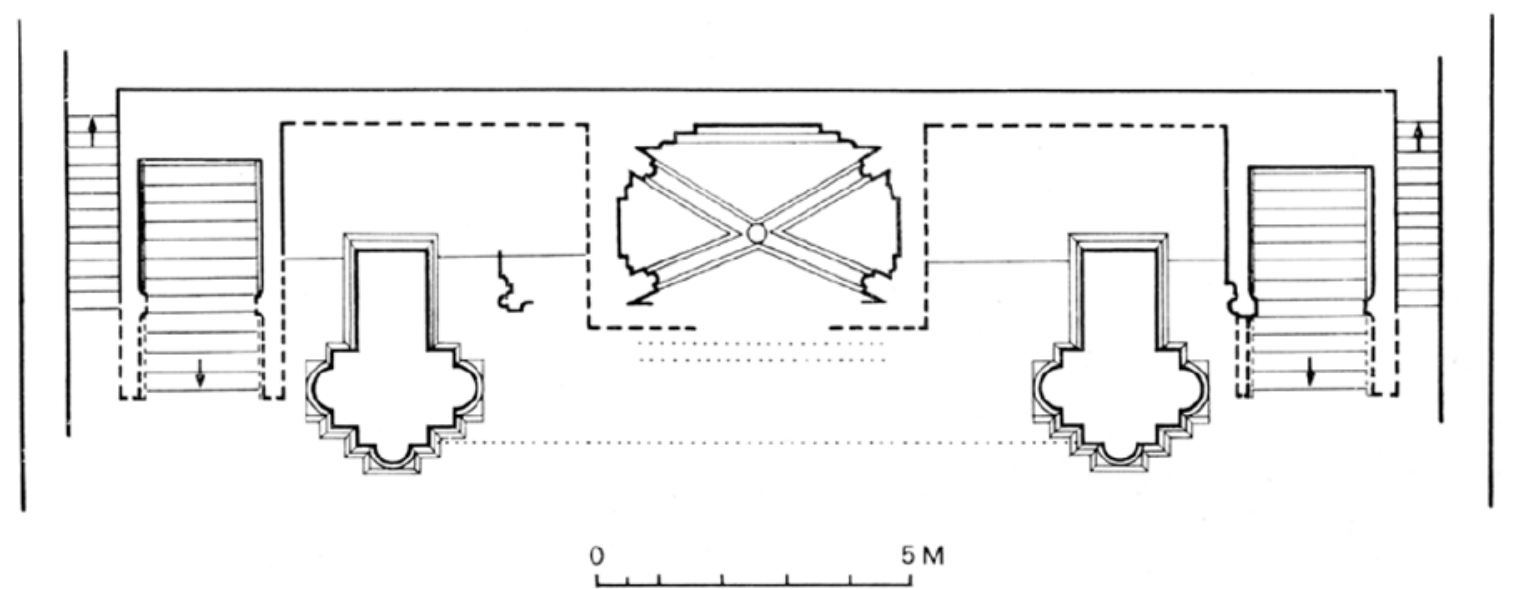

3. ábra. A székesegyház szentélyrekesztőjének alaprajza

épen fennmaradt egyik alak $73 \times 25 \mathrm{~cm}$ méretü. ${ }^{20}$ Feltehetően ide sorolható a feltámadó lelkeket ábrázoló dombormű is - tehát az északi lejáró keleti oldalán ez a kompozíció semmiképp sem férhetett el. Egy további nehézséget okoz, hogy a Sámson fakitépés ábrázoló dombormű kőkerete mögül került elő az oltárbaldachin pikkelyes tetejének egy részlete. ${ }^{21}$

A domborművek eredeti lejárati funkcióját leginkább a pásztorokat ábrázoló sarokdomborművel magyarázzák. E faragvány negatív sarkot mintáz a déli lejáró ÉK-i sarkában. Azonban ettől a ténytől még nem lehetetlenedik el a nyugati homlokzaton való elhelyezése, hiszen számos esetben ismerünk hasonló elhelyezésű faragványokat, elég itt csak az Arlesi St. Trophime katedrális Ny-i kapu, és a St. Gilles-du-Gard apátsági templom Ny-i hármas kapu szemöldökfrízére gondolni. (4. ábra)

A domborműveken észlelhető állapotromlást, patinás felületet Szőnyi a külső helyen való alkalmazással magyarázta, ennek alapján feltételezhető, hogy azok a szabadban beépítésre kerültek. ${ }^{22}$

A keretek elhelyezése már a korabeli ábrázolások alapján sem egyértelmü. Míg Henszlmann 1876-ban megjelent könyvében a Három királyok hódolata fölötti felső, madaras keretnek csak egy kis részlete látszik in situ a későbbi átboltozás miatt, addig a néhány évvel később megjelent, Az Osztrák-Magyar Monarchia Írásban és Képben kötetben már kiegészítéssel, illetve egy fölötte lévő, szélesebb kereteléssel ábrázolják a jelenetet. ${ }^{23}$ (5. ábra) Íly formán eléggé bizonytalan a keretek a lejáróban elfoglalt eredeti helyzete. Így kérdésessé válik az egyik

20 Tóth 1994. 141, 137. Az aggastyánok ábrázolása Nagy Emese állitásával szemben nem egyedül Franciaországban van jelen, bár ténylegesen ott teljesedett ki a nagy Utolsó İtéletet ábrázoló portálszobrászatban. Emellett számtalan spanyol példát is ismerünk, de talán a Ripolli Szűz Mária templom nyugati homlokzata a leglátványosabb. A három királyok egy ágyban történő ábrázolása hasonlóképpen nem csak Pécsett tủnik fel, hanem többek között Spanyolország több románkori templomában is megjelenik (Id. Iglesia S Domingo Soria, Tarragonai katedrális).

21 Gosztonyi 1939. 252., Szőnyi 1906. 35-36.

22 Szönyi 1906. 110.

23 Henszlmann 1876. 65. o. 62. ábra, Pasteiner 1896. https://www. tankonyvtar.hu/en/tartalom/tkt/osztrak-magyar/ch16s04.html keretben ábrázolt angyalalak (melyet a Három királyok hódolata fölé helyeztek), de amely eredetileg minden bizonnyal más jelenet fölött lehetett (pl a pásztorok felfelé tekintgető arca, vagy a három királyok álma fölé). ${ }^{24}$

\section{A székesegyház későbbi átépítése, adományok}

Az alábbiak szerint valószínűsíthető, hogy a szentélyrekesztő és a többi faragvány elbontása feltehetően az 1500 körüli gótikus átépítésnek volt köszönhető, mivel darabjait a templomhajó közbülső pilléreinek téglalap alakúvá történő átalakításakor használták fel az alapozásban és a falazatban. Az új boltozás miatt szükséges volt a pillérek megerősítése, amelyhez az elbontott anyagot is felhasználták. ${ }^{25} \mathrm{~A}$ dombormüvek és faragványok áthelyezésekor csak azoknak egy részét használták fel, más részüket a falak megerősítésébe építették be, így fordulhatott elő, hogy egy aggastyánt ábrázoló faragás a föhajó D-i falából, a déli mellékhajóból, míg egy angyal alakja a gótikus diadalívből került elő. Ezeken a befalazott darabokon jó állapotban megmaradt festéknyomok is találhatók. ${ }^{26}$

Gerecze tanulmányából kiderül, hogy a románkori fejezeteket a később átalakított pillérekre vissza is helyezték, így úgy tünik, hogy a románkori faragványok értékével a gótikus átépítés során tisztában lehettek, talán ezért törekedtek egy részük megmentésére, bemutatására. ${ }^{27} \mathrm{E}$ sor probléma felveti annak a lehetőségét, hogy a dombormüsorozat utólagosan került elhelyezésre a lejáratoknál.

A székesegyház építési periódusaira utalhatnak az írott forrásokban megjelenő adományok, még abban az esetben is, ha nincs kihangsúlyozva, hogy azt a templom építésére kell fordítani. Az alapítás megerősítését, a pécsi egyházmegye határainak újbóli kijelölését és

24 Nagy 1983. 331. Nagy Emese a három királyok hódolata fölé helyezett angyalos keret alapján bizonyítékként tekint a keretek és a jelenetek összetartozására. A Biblia azonban a három királyok hódolata kapcsán nem emlékezik meg az angyali jelenlétről.

25 Buzás 2013. 23.

26 Tóth 1994. 143.

27 Gerecze 1897. 116. 


\section{ÉS A SÁMSON CIKLUS ÉRTELMEZÉSÉHEZ}
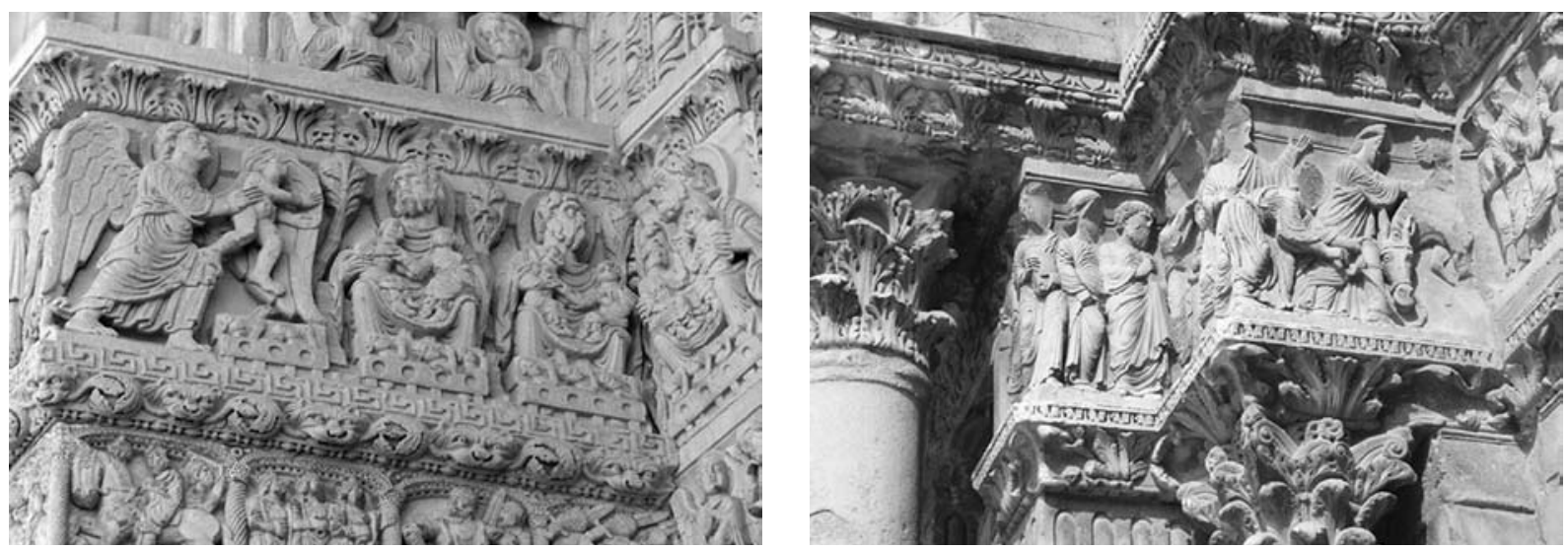

4. ábra. Az Arlesi St. Trophime katedrális homlokzatán Ábrahám, Izsák és Jákob megjelenítése és a St. Gilles-du-Gardi monostor kapuján a bevonulás Jeruzsálembe történet ábrázolása
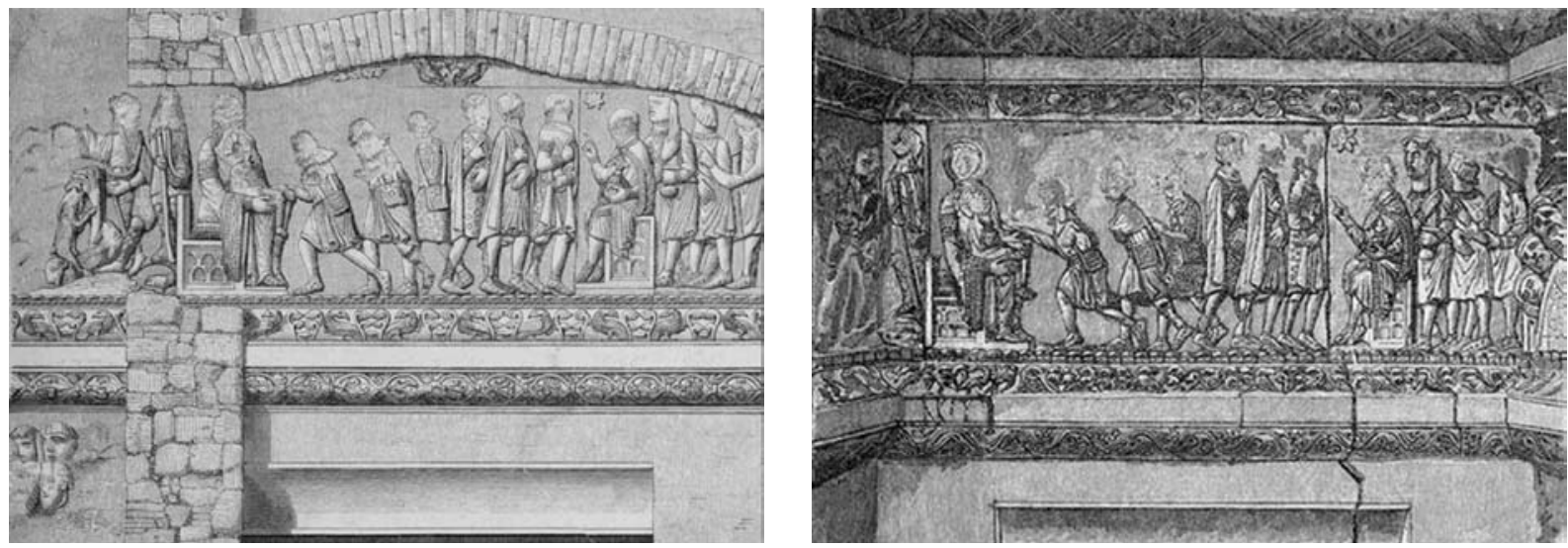

5. ábra. A Henszlmann-féle és a későbbi ábrázolás közti eltérés

különböző kiváltságok adományozását tartalmazza Szent László 1093-a bullája, ekkor már bizonyára zajlott a tűzvész utáni építkezés. III. Béla 1190-ben az adományokat újból megerősítette és kibővítette - ez a támogatás a Kalán püspök idejében folytatott építkezésekhez kapcsolódhat. ${ }^{28}$ Azonban ezzel még nem ért véget a királyi támogatás, hiszen 1235 körül II. András újabb megerősítést és birtok-, valamint pénzadományt juttat a püspökségnek.

A gótikus átépítés kezdete még jobban datálható, hiszen 1457-ben Angeli János bíboros elrendelte, hogy a végrendelet nélkül elhunyt kanonokok összes vagyonát a székesegyház újraépítésére, fenntartására használják fel. Ezek a munkálatok a századfordulóig tartottak, míg végül 1501-ben Zsigmond püspök a székesegyházat a helyreállítás után Jakab baráttal kifestette. ${ }^{29}$

Érdekes problémát vet fel az inkrusztált faragványok köre, amely anyagában és kialakításában ugyan más, mint az Esztergomi Porta Speciosa, azonban mindenképpen annak hatását mutatja. A Jákob/lzsák ábrázolás alsó részének töredékessége alapján is megállapítható,

28 Gosztonyi 1939. 79. Calanus idejében már 2 káptalan is müködik Pécsett, a Szt. Péter székeskáptalan és a Szt. János társaskáptalan.

29 Gosztonyi 1939. 81. hogy nem egymagában állt, feltehetően, egy az esztergomi székesegyház kapujához hasonló bejárat részét képezte a ma is fennmaradt nyugati márvány kapuval együtt. A III. Béla esztergomi építkezéseinek köréhez tartozó mühely kisugárzása tehát elért Pécsre is, azonban a kivitelezésben, a redők végpontjában vésett kettős félkör alapján, a lejárat faragványainak elkészítésében is közremüködő mester vett részt. A kivitelezéshez nem a gerecsei/tardosi vörös mészkövet használták, hanem a pécsi fehér márvány spoliák átfaragásával jutottak nyersanyaghoz. A románkori templom építkezésének utolsó fázisában elkészült díszkapu révén a nyugati homlokzati eredeti elképzelés szerinti kialakítása módosulhatott.

\section{A Sámson ciklus részlete}

A Sámson képsor töredékesen maradt fenn, így úgy tủnik, hogy egyes jelenetek hiányoznak a ciklusból. (6. ábra) A többé-kevésbé épen maradt jelenetek közé tartozik a románkorban közkedvelt ábrázolás - Sámson harca az oroszlánnal, a vak Sámson megjelenítése, a ritka fanyűvő ábrázolás és a Dágon templom szétrombolásának bemutatása. Az utolsó alakban talán Sámson szolgáját láthatjuk, aki a hős ruháit és jelvényeit(?) viszi 

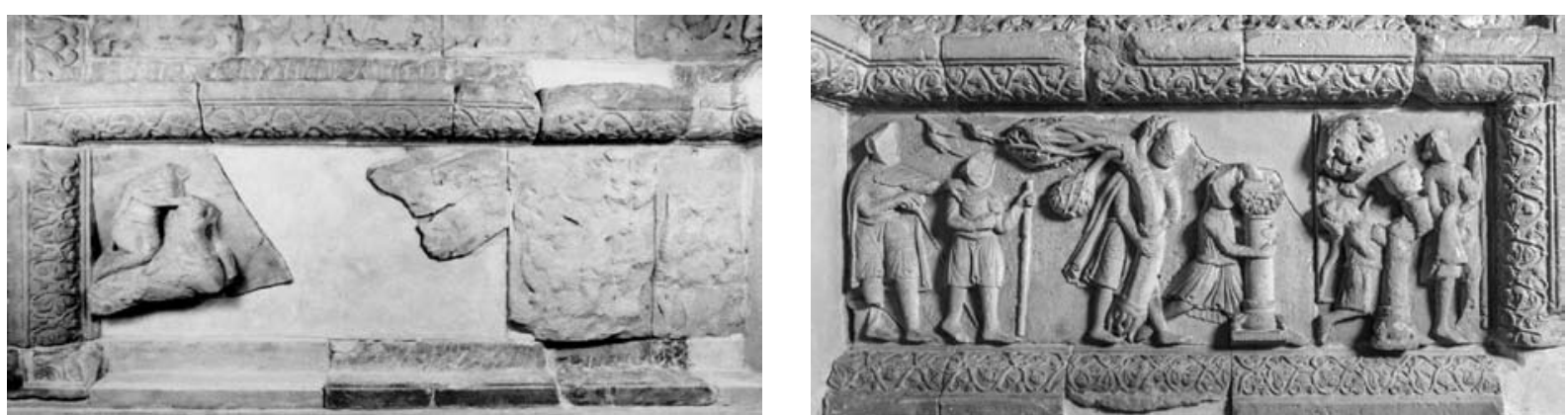

6. ábra. A pécsi Sámson ciklus maradványa

el. A Sámson ciklus további részletei bizonytalanok: a Delila történet rekonstrukció, a gázai kapuk kiemelése, valamint Sámson harca a szamár állkapcsával hipotézis. A déli kriptalejárat kapujától É-ra eső részen az oroszlánnal folyó küzdelem melletti kő rendkívül töredékes, nem értelmezhető, a Delilát ábrázoló kövön $(79 \times 46 \mathrm{~cm})$, annak nagyfokú sérülése miatt egyértelmüen csak négy férfifej látszik, míg az ezt követö kövön $(79 \times 28 \mathrm{~cm})$ pedig csak néhány redő és fejvonal azonositható. ${ }^{30}$

A Sámson ábrázolások a románkori müvészetben rendkívül elterjedtek voltak. Előszeretettel jelenítették meg a hős harcát az oroszlánnal, amely valamilyen formában szinte minden templom falát díszítette. Legtöbb esetben Sámson az oroszlán hátán átvetett lábakkal található, amint annak száját szétfeszti (pl. Párma, Arles, Autun, Vézelay, Santa Maria del lago Moscufo ambó, Esztergom). Ritkább a lábbal átkulcsolt fej (pl. S. Calmin de Mozac, Notre-Dame des Doms in Avignon) és az egy lábbal az oroszlánra tipró megoldás (pl. Moissac, Sant Cugat del Vallés), az oroszlán előtt álló Sámson megjelenítés (pl. Serrabone, Sélestat, Pavia), vagy a pécsi ciklusban megfigyelhető rátérdelő Sámson ábrázolás (pl. Speyer, Anzy-le-Duc, Vouvant, Bécsi Stephanskirche), míg annak somogyvári párhuzama, ahol Sámson az oroszlán hátán áll, feltehetően kompozíciós nehézségből adódóan, egyedi. ${ }^{31}$ Hasonlóképpen különálló a gurki apátság timpanonjának Sámsona, akit koronás fővel, az oroszlán előtt guggolva jelenítenek meg. Az ábrázolás másik érdekessége a kép jobb és bal oldalán látható madáralak.

A másik, előszeretettel ábrázolt jelenet Sámson és Delila története volt. Ám még az előző ábrázolás - Sámson harca az oroszlánnal - önmagában is megjelenhetett, addig a Delila történetet legtöbbször már a ciklus részeként ábrázolták. Ilyen Sámson ciklusok az oroszlános ábrázoláshoz képest ritkábbak, vagy nagyobb méretü oszlop- és pillérfőkön, ritkábban reliefeken, timpanonokon jelennek meg. Általánosan a Delila történetből a hajvágást ábrázolták (néha a megvakítással együtt), ahol a Delila vagy egyedül, vagy a filiszteusokkal együtt jelenik meg (pl. Vouvant, La Sauve-Majeure, Notre-Da-

30 Szőnyi 1906. 130-131. 220. szám. Szőnyi szerint a dombormű azt a jelenetet ábrázolja, amikor Delila levágja Sámson haját. A másik dombormü száma: 221.

31 Henszlmann 1876. Henszlmann a gyulafehérvári székesegyház mellékapszisa külsején található oszlopok egyike fölött oroszlánt fojtó Sámson ábrázolásról ír. me des Doms in Avignon, San Pedro el Viejo (Huesca), Grande-Sauve apátság, Sainte Gertrude de Nibelles - itt a timpanon másik felén a megvakítás jelentét ábrázolták, Aulnay-de-Saintonge - ahol a hajvágást és megkötést egy jelenetbe sürítik). Egyedi az Arlesi S. Trophime templom nyugati homlokzatán megjelenített oszloplábazat, ahol Delila megkötözi a hőst. A legyőzött Sámson jelenítik meg a Vezelayi S.Madeleine templom oszlopfőjén, ahol Delila filiszteusok körében a legyengített Sámsont egy nyakába akasztott láncon vezeti.

A gázai kapu kiemelése szintén a ciklus részét képezte, általában Sámson vállán jelenítik meg a kiszedett kapuszárnyakat (pl. La Sauve-Majeure, Monreale, Notre-Dame des Doms in Avignon, Grande-Sauve apátság, Sainte Gertrude de Nibelles, nápolyi S. Restituta templom).

Sámson bibliai történetében a filiszteusok elleni harc egyik eszköze egy szamárállkapocs. Ennek ábrázolása aránylag ritkábban fordul elő (pl. Monreale, nápolyi S. Restituta templom).

A pécsi reliefen is megtalálható, Dágon templomának összedöntéséről szóló ábrázolás széles körben elterjedt volt. Az egy oszlopot átkaroló Sámson nem egyedi, hasonló megoldást pl. a spanyol Aguilar de Bureba Iglesia de la Asuncion templom diadalívénél lévő ábrázoláson ${ }^{32}$ és a Monrealei monostor oszlopfőjén is találunk. A Sainte Gertrude de Nibelles templom É-i kapujának Sámson ciklusa részben a timpanonban, részint a kapubéllet két oszlopában foglal helyet, ahol baloldalt látható az oszlopot átkaroló Sámson, még jobb oldalt a gázai kaput vállára emelő alak. Még közelebbi párhuzamot jelent az Autuni Saint Lazare templom oszlopfejezete, ahol a vak Sámsont kísérő ifjú alakja is megjelenik, ahogyan azt egy Savigny Szt. Márton apátsági templomból származó pilléren is ábrázolták. Bevett szokásnak tűnik, hogy a filiszteusokat az oszlopra szerelt kis kerek vagy szögletes épületben kitekintő arcként jelenítik meg, ahogy eredetileg a pécsi kövön is előfordulhatott, és ahogy a széttört oszlopnál ábrázolták. Ennek okát a kompozíciós tér szűk volta adta, bár ezzel Pécsett nem kellett számolni, de láthatóan a francia területen kidolgozott ábrázolásmódtól nem tudott eltérni az alkotó. Más ábrázolásokon két oszlopot jelenítettek meg, ahogyan az avignoni Notre-Dame des Domsból származó oszlopfőn is. Hasonlóképpan a Piemonti Sacra di San Michele bencés apátság Zodiákus

32 Érdekesség, hogy a diadalív oszlopfőjén a Sámson történetböl ezt a részletet emelték ki. Sámson mellett Dávidot láthatjuk parittyával. 


\section{ÉS A SÁMSON CIKLUS ÉRTELMEZÉSÉHEZ}
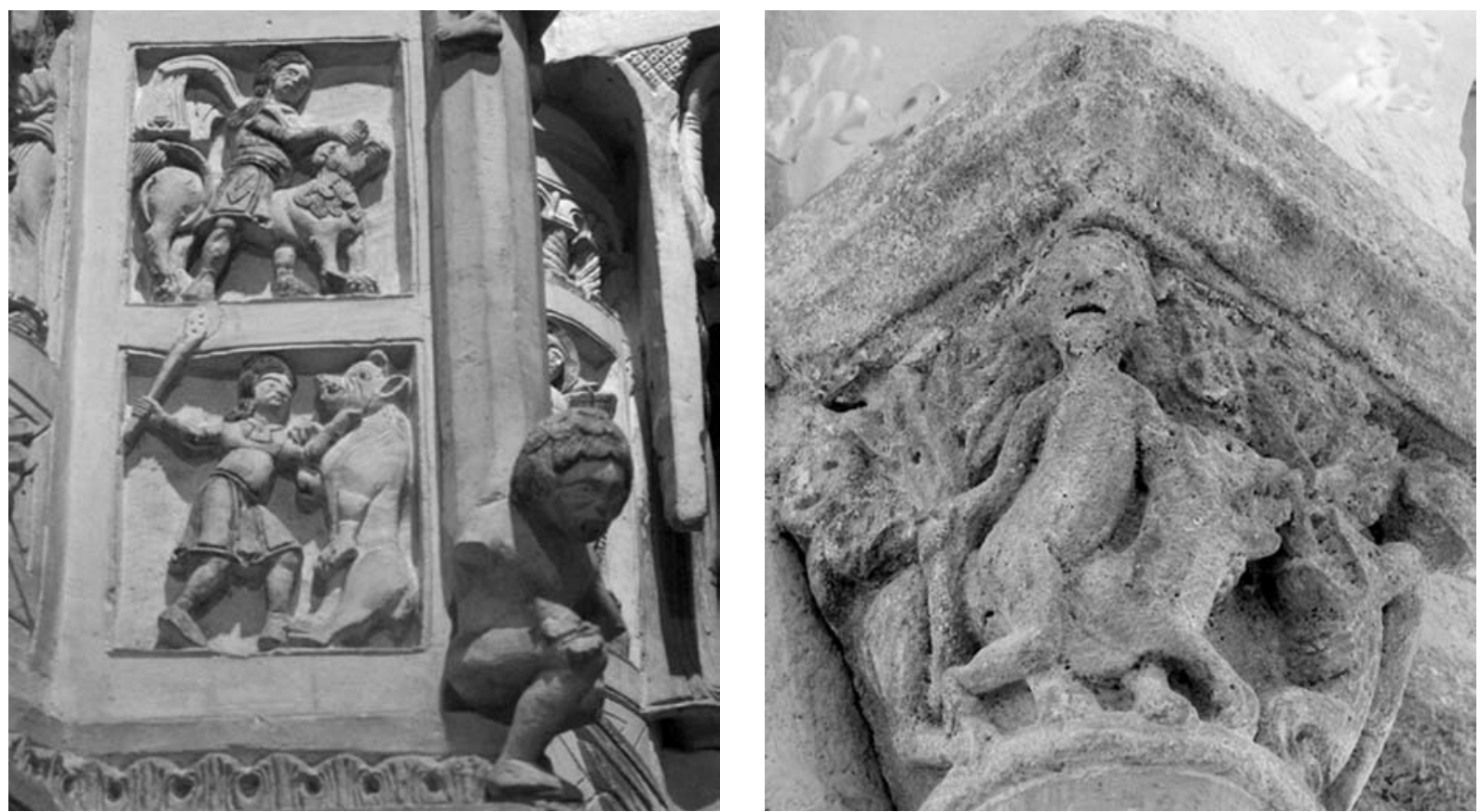

7. ábra. Nem bibliai alapú Sámson ábrázolások - harca a medvével, vademberként való ábrázolása

kapujának Sámsonos oszlopfőjén két oszlop közti boltozat alatt ábrázolták a filiszteusokat. A Savigny pilléren ábrázolt Dágon templom összedöntése eltér a megszokottól, itt Sámson figuráját magában az épületben ábrázolják, amint azt magára dönti. A pécsi ciklus széttört oszlopának ez az egyetlen távoli párhuzama.

A pécsi Sámson ciklus leginkább vitatott darabja a fakitépést ábrázoló részlet. Már Scheiber Sándor több analógiát felvonultatott kutatásai során, elég csak Alspach, Limburg, Maienfeld és Remagen esetét feleleveníteni. ${ }^{33}$ Hasonlóan nem a bibliai történet részét képezi a Savigny pillér ábrázolása, ahol a négy oldalból három Sámson történetét dolgozza fel (harca az oroszlánnal, megvakultan egy ifjú vezeti, ledönti Dágon templomát), a negyedik oldalon pedig egy növényi indák közé szorult mezítelen férfialak látható, amelyet $\mathrm{K}$. Ambrose a pécsi körhöz köt, de amit elég nehezen lehet fakitépésnek értelmezni, és sokkal inkább a bün hálójában vergődő ember képét jeleníti meg. ${ }^{34}$ (7. ábra c.)

A Bibliai megfogalmazástól azonban nem csak a fakitépés jelenete tér el. Az abruzzói Santa Maria del Lago a Moscufo ambóját Nicodemus mester 1159ben készítette el, ahol Sámsont először egy oroszlánnal küzdve ábrázolja, majd alatta egyik kezével egy medve nyakát szorítja, míg másik kezével egy bottal/ buzogánnyal készül lesújtani. Hosszú haja alapján egyértelmünek tűnik a felső ábrázolással történő egybekapcsolása. Ugyanezt a két jelenetet ismétli meg az 1166-ban elkészített pulpitusán is a San Stefan Cugnoli templomban. ${ }^{35}$ (7. ábra a.)

33 Scheiber 1962. 68-71.

34 Ambrose.2013. 51-53., Fig. 12

35 A medvével történő harc az 1150 körül keletkezett S. Maria in Valle Porclaneta templom pulpitusát is díszíti, amelynek megalkotója feltehetően szintén Nicodemus volt.

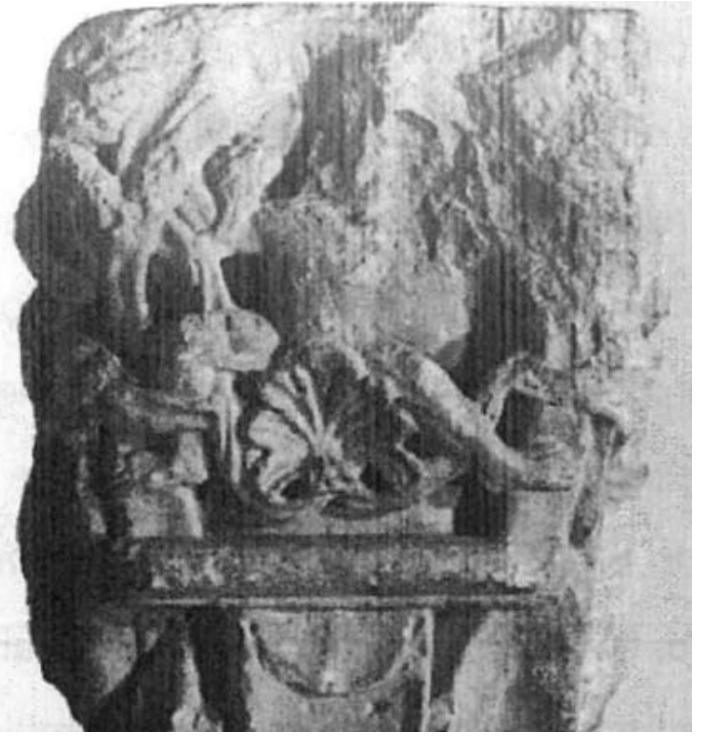

A Sámson történet teljesebb feldolgozása aránylag ritka, a nápolyi S. Restituta templom reliefje (ahol a magvakítás mellett az összekötött farkú rókák történet is látható) és a Monrealei apátság komplex oszlopfője mellett (ahol a találós kérdéses és Sámson látogatása a gázai prostituáltnál jeleneteket is ábrázolták) legteljesebben mozaikon fordul elő (pl. a Szt. Gereon templom kriptamozaikja, az Aostai Sant Orso templom és az Asti Santa Maria Assunta e San Gottardo katedrális mozaikja).

A Sámson történet nem csak a kőfaragványokat díszítette, hanem más művészeti ágakban is előszeretettel ábrázolták, a falfestmények és könyvábrázolások mellett, a fémtárgyakon és játékpionokon is megjelent. Ezeken az elefántcsontból faragott kerek pionokon a 
bibliai történet több részlete is feltűnik - Sámson az öszszekötött farkú rókákkal, harca a szamárállkapoccsal, és a Delila történet. A Sámson pionok pogány megfelelőjeként, a táblajáték ellentétes oldalán Herkules története elevenedik meg.

\section{Sámson alakjának középkori párhuzamai}

Pécsett Sámson élete a Krisztológiai ciklussal lett párhuzamba állítva. Ez egyáltalán nem véletlen, hiszen már az ókorban kialakult az az elképzelés, hogy a sámsoni életpálya sokban előre vetíti a krisztusi utat. Sámsonra, akinek neve nap jelentésű, a filiszteusoktól elnyomott zsidók messiásként tekintettek. A 4. és 5 . században többen, köztük Szt. Ambrus felvetette a Krisztussal történő összehasonlítást, amelyet később Sevillai Izidor és az admonti iskola megalapítója, Gottfried apát is osztott. ${ }^{36}$ Sámson, a népének védelmezője és az árulás áldozata allegórikusan Krisztust személyesíti meg. Már nevében is (Nazarénus/Názáreti) összefonódik a két alak. Mindketten Istennek szenteltek (a nazarénusok nem ihattak alkoholt és nem vágathatták le a hajukat), és mindkettő születéséröl angyal adott hírt. Sámson oroszlán elleni küzdelme Krisztus Sátán elleni küzdelmével lett párhuzamba állítva, a gázai kapuk, feltámadáskor a sír szája elöl elgörgetett kőre, vagy az alvilági kapuk megnyitására utaltak. Sámson vállára vetett kapuszárnyak pedig a keresztfát idézték. A Dágon templom lerombolásával vállalt önfeláldozása, párhuzamba állítható Jézus kereszthalálával. A középkori ember számára az azonosításhoz további példák özöne állt rendelkezésre. ${ }^{37}$

A krisztusi párhuzam mellett azonban adódik egy másik, ókori azonosítási lehetőség is, név szerint Herkulessel, akinek története a középkor embere számára is ismert volt. Herkulessel leginkább nagy ereje köti össze. Euripidés Héraklés drámájában a Thébába hazatérő hős Héra által rábocsátott tébolyában többek között a bezárt ajtót kiszakítja helyéről, és vérengzéséből csak Pallas Athéné tudja kiszakítani, azáltal, hogy egy szikladarabot dob rá, amitől a hős egy oszlopra zuhan és összeesik. Ekkor apja, Amphitryón egy oszlophoz kötözi. A kapukitépés, az oszlop megjelenítése, az épület lerombolása, a megkötözöttség is összekapcsolja a két alakot. Mindkét hős puszta kezével tép szét egy oroszlánt és mindkettőt egy asszony győzi le (Sámsont Delilah, Herkulest Déianeirá). A hellénisztikus korban, Apollónios Rhodios eposzában Herkules egy fát tép ki gyökerestől, talán ez a történet kerülhetett át a pécsi Sámson ciklusba. ${ }^{38}$

A harmadik párhuzamot Sámsonnak a középkori vademberrel való azonosítása jelenti. A mesék vadembere a természetben él, és a természetből táplálkozik, és vadságát is onnan meríti. Sámson, aki oroszlánokkal küzd meg, rókákat fog el, sziklaodúba menekül, vadmézet eszik, fegyverként szamárállkapcsot használ, jól be-

\footnotetext{
36 Dinkova Bruun 2012.

37 A gurki apátsági templom timpanonjában a koronás Sámson fej talán szintén Krisztusra utal.
}

38 Horváth 2011. 18-19, 22. leillik ebbe a képbe. Állatias vadsága, dühkitörési révén veszélyes. A vademberrel való azonosítás a kőfaragványokban is fellelhetö, elég csak a Savigny pillérre vagy a Saint-Nectaire (Puy-de Dome) templom oszlopfőjére gondolnunk. Mindkét esetben Sámsont meztelenül ábrázolják, azonban míg az első esetben az indák által átölelt, szinte megbéklyózott férfit ábrázoltak, addig a második esetben egy oroszlán hátán találjuk, igaz itt is növényekkel körülvéve. (7. ábra b, c.)

Sámson alakja tehát összetett, több rétegü értelmezésre ad lehetőséget a középkorban. A fentiek alapján megállapíthatjuk, hogy a Sámson karakter összetettsége okozhatta, hogy több esetben, nemcsak a szorosan vett bibliai szövegrészek kerültek ábrázolásra, hanem ennek egy kitágított, apokríf és folklór elemekkel tarkított középkori változata.

\section{Hatások a pécsi székesegyház nyugati homlokzatá- nak kialakításához}

A pécsi 12. század végén keletkezett kőfaragványok, reliefek elsősorban francia (burgundi-provanszi) hatást tükröznek.

A kapcsolódási pontok feltárása nem egyszerü, mivel a legtöbb esetben többrétegü, többirányú, egymásra ható folyamat eredménye. Ennek az ábrázolásmódnak a kiindulópontja mindenképp Clunyi, ahonnan a reformszellem mellett művészeti hatások is érkeztek. A Clunyi nagy portál a Clunyi III templom 12. századi átépítésének befejező szakaszában, 1110 és 1120 között készült (később egy narthex épült elé), és hatása - a clunyi kongregáció reformszelleméhez hasonlóan - sok helyen érződött. Ez a meghatározó, síkból előugró nagyméretü kapukompozíció ihlethette meg a Toulouse-i St. Sernin bazilika D-i, Miégeville kapuját, amelynek timpanonjában Krisztus mennybemenetelét ábrázolták. Hasonló alkotás a Moissaci apátsági templom Ítélkező Krisztust ábrázoló DNy-i kapuja. Ezeknek a falsíkből elöreugró portáloknak továbbgondolt változata jelenik meg az Arlesi St. Trophime katedrális Ny-i, Utolsó Ítéletet ábrázoló, komplex architektúrájú kapuján a 12. sz. második felében. $E$ franciás kör olasz variánsa a Fidenzai dóm 1178-1196 között, Benedetto Antellami által kialakított nyugati homlokzata, ahol a hármas kapu középső eleme mind méretben, mind az épület síkjából való kiemelkedés tekintetében meghatározó.

A nyugati homlokzat teljes felületének díszítése, egy másik irányból érkező hatás. A már említett spanyol Ripolli apátsági templom homlokzata mellett hasonló, Utolsó Ítéletet ábrázoló, több sorban az ó- és újszövetséget megjelenítő ábrázolás a poitiersi Notre-Dame le Grande templom díszes homlokzatán látható. Némileg leegyszerüsítve német területen is előfordulnak, elég csak a regensburgi $\mathrm{S}$. Jakab templom homlokzatára gondolnunk. Más jellegű faragványokkal díszítették a 12. sz. elején a Páviai S. Michele templom három kapus homlokzatát. Ezeknél a példáknál a középső kapu sem méretében, sem struktúrájában nem domináns. 
A pécsi székesegyház 12. századi átalakítása, faragványokkal való ékesítése a 18 . századi rajzok alapján egy olyan hármas kapuval rendelkező, sávosan osztott Utolsó Ítéletet ábrázoló nyugati homlokzatot feltételez, amely az építkezés idején módosult. Minden bizonnyal a Porta Speciosa hatására, egy középső díszkapu kialakítását kezdték meg. Ennek a díszkapunak feltehetően részét képezte a római-kori márványból elkészített nyugati kapun kívül a Jákob/lzsák nevével fémjelzett faragvány is. Míg a szentélyrekesztő és a Szent Kereszt oltár kialakítása bizonyosan már az előző püspök, II. Makár idején elkezdődött, a nyugati homlokzat kialakításának terve minden bizonnyal Kalán püspökben érlelődött meg. A kiemelkedő egyházfi a feltételezések alapján Franciaországban tanult, majd III. Béla kancellárjaként, pécsi püspökként, Délvidéki kormányzóként, Horvátország és Dalmácia gubernátoraként széles látókörre tehetett szert. Nem mellesleg a pápától a pallium viselési jogot is megkapta. 1204-ben a megüresedett esztergomi érseki székbe pályázott, azonban ezt végül riválisa, János kalocsai érsek töltötte be. ${ }^{39} \mathrm{~A}$ díszkapu (egy pécsi Porta Speciosa megalkotását) - talán a mellőzése révén, vagy 1218-ban bekövetkezett halála miatt nem készítette el.

\section{Összefoglalás}

A 18. századi ábrázoláson megjelenített épület mindenképp több románkori építési periódus során alakult ki. Az altemplom megépítése után a szentély építéséhez kapcsolódóan megépült a K-i toronypár még feltehetően a 11-12. sz. fordulóján alacsonyabb főapszissal és kisebb méretű románkori ablakokkal. Szent László által adományozott kiváltságok a megkezdett építkezés folytatását szolgálták, de úgy tűnik, hogy a megrekedt építkezés csak a 12 . sz. végén, egy újabb adomány révén folytatódott. Talán ehhez kapcsolódik a nagyszabású Ny-i homlokzat kialakítása.

\section{Irodalom}

KIRKAMBROSE 2013: The marvellous and the monstrous in the sculpture of Twelfth-Century Europe. 2013. UK

BoRos LÁsZLó 2002: Falkutatás a pécsi bazilika altemplomában. Pécsi Szemle V/2. 2002. 5-20.

BuzÁs GeRgely 2013: A pécsi székesegyházak a román korban. Archaeologia - Altum Castrum Online Visegrád 2013.

GRETI DINKOVA BRUUN 2012: The story of Samson in medieval literary discourse. In: The Oxford Handbook of Medieval Latin Literature. (szerk: Ralph Hexter-David Townsend) 2012.

GERECZE PÉTER 1897: A pécsi székesegyház oltársátra és többi szobrászati maradványa. Arch. Közl. XX. 1897. 72-130.

GosztonYI GyULA 1939: A pécsi székesegyház eredete. Pécs 1939.

HENSZLMANN IMRE 1876: Magyarország ó-keresztyén, román és átmenet stylü mü-emlékeinek rövid ismertetése. Budapest 1876.

HoRváTH Judit 2011: Sámson és Héraklés. In: Ókor 2011. 10. évf. 3. sz. 18-23.
KoszTA LÁszLó 2009: A pécsi püspökök a 14. század közepéig. In: A pécsi egyházmegye története I. A középkor évszázadai (10091543) (szerk: Fedeles Tamás - Sabrak Gábor - Sümegi József) Pécs 2009

NAGY EMESE 1983: Adatok a pécsi székesegyház altemplomi lejáratainak problematikájához. In: Építés-, Építészettudomány 15. 1983. 327-334.

PASTEINER GyULA 1896: Építészeti emlékek a Dunán túl. In: Az OsztrákMagyar Monarchia Írásban és Képben IV. Budapest 1896.

SCHEIBER SÁNDOR 1962: A fakitépő Sámson párhuzamai és forrásai. In: Archaeológia Értesítő 89., Budapest 1962. 68-71.

SzŐNYI OTTÓ 1906: A pécsi püspöki múzeum kőtára. Pécs 1906.

TóTH MELINDA 1994: A pécsi székesegyház kőszobrászati díszítése a románkorban. In: Pannonia Regia. (szerk: Mikó Árpád - Takács Imre) Budapest 1994. 123-147. 


\title{
Additional information to the 12. C. construction of the cathedral of Pécs and to the interpretation of the Samson cycle
}

\author{
CSILLA M. ARADI
}

The archaeological excavations, art historical investigations, as well as the 18-19. C survey and other representations all yielded to the identification of traces of the 12. C constructions on the Basilica of Pécs. The enlargement of a smaller Romanesque window on the North side of the main apse, the position of cornices, the walled in arch on the West front, the position of side windows, the plan of a Western gallery, the chronological separation of the two pair of towers all add up to at least two Romanesque periods. It is probable that the cathedral had a largely decorated Western front with a Last Judgment scene, which was relocated during the gothic period. The stone carvings reflecting French influence originally were not placed at the crypt entrance. The irregularity of the entrances, the differences in measurement and form between the two doors, the original window in the location of the Southern entrance all give evidence. A group of carvings was found in secondary position in the gothic pillars and walls, and behind the Samson relief a piece of the altar baldachin was located. Further anomalies could be traced at the dividing frame ornament of the entrances.

The fragmentary Samson cycle of Pécs is one of the fullest representations of the Biblical story in the Romanesque period. Out of the different descriptions the one depicting the tree-pulling Samson has no Biblical analogy. Its parallels were highlighted by Scheiber. Other non Biblical representations of the Samson narrative his fight with a bear - can be traced in Southern Italy. Alongside with Christ, Hercules and the wild man show correlation with the medieval Samson figure. 